\title{
Serine-Protein Kinase ATM
}

National Cancer Institute

\section{Source}

National Cancer Institute. Serine-Protein Kinase ATM. NCI Thesaurus. Code C17924.

Serine-protein kinase ATM (3056 aa, $351 \mathrm{kDa}$ ) is encoded by the human AT M gene. This protein is involved in DNA damage-induced protein phosphorylation. 